Snežana Milićević ${ }^{1}$

Milena Podovac ${ }^{2}$

Nataša Đorđević ${ }^{3}$

University of Kragujevac, Faculty of

Hotel Management and Tourism in Vrnjačka Banja
SCIENTIFIC REVIEW ARTICLE

doi: $10.5937 /$ ekonomika2002075M

Received: February, 22. 2019.

Accepted: April, 11. 2020.

\title{
LOCAL RESIDENTS' ATTITUDES TOWARDS TOURISM EVENTS: A CASE STUDY OF THE CARNIVAL OF VRNJCI, SERBIA ${ }^{4}$
}

\begin{abstract}
Elements of the tourism destination offer such as manifestations contributing to economic prosperity and creating a positive image of the destination may create pressure on the natural and cultural resources of the destination. Since active support of the local residents is crucial for the future planning and development of tourism, it is necessary to evaluate the tourism events by considering their impact on the quality of life of the local residents. This paper analyzes the residents 'attitudes towards the event that has been taking place in Vrnjačka Banja for 14 years - the Carnival of Vrnjci. The applied method is a survey, which was conducted on a sample of 300 local residents. Research shows that the Carnival of Vrnjci has a positive impact on the quality of life of the local residents. In addition, the results indicate that there is no statistically significant difference between the attitudes of residents of different socio-demographic characteristics about the effects of Carnival of Vrnjci on their quality of life.
\end{abstract}

Key words: local residents' attitudes, tourism events, impacts of tourism, Carnival of Vrnjci, Vrnjačka Banja.

JEL classification: L83, Z30, Z32

\section{СТАВОВИ ЛОКАЛНОГ СТАНОВНИШТВА О ТУРИСТИЧКИМ МАНИФЕСТАЦИЈАМА: СТУДИЈА СЛУЧАЈА ВРЊАЧКИ КАРНЕВАЛ}

\section{Апстракт}

Елементи туристичке понуде дестинације као што су манифестације поред тога што могу допринети економском просперитету, стварану позитивног

\footnotetext{
${ }^{1}$ snezana.milicevic@kg.ac.rs, ORCID ID.0000-0002-1972-9585

2 milena.podovac@kg.ac.rs, ORCID ID. 0000-0002-0709-2927

${ }^{3}$ natasa.djordjevic@kg.ac.rs, ORCID ID.0000-0002-3630-6867

${ }^{4}$ Project no. III 46006 - Sustainable agriculture and rural development in the function of accomplishing strategic objectives of the Republic of Serbia in the Danube region, financed by the Ministry of Education, Science and Technological Development of the Republic of Serbia. Project period: 2011-2019.
} 
имица дестинације, могу креирати и притисак на природне и културне ресурсе дестинације. Како за будуће планирағе и развој туризма кључни значај има активна подрика локалне заједнице, потребно је вриити евалуацију манифестација сагледавањем юиховог утииаја на квалитет живота локалне заједнице. У раду су анализирани ставови локалног становништва о манифестацији која се већ 14 година одржава у врьачкој бањи - међународни врьачки карневал. Примењена је метода анкетног истраживања на узорку од 300 испитаника. Истраживање показује да манифестачија врьачки карневал има позитиван утицај на квалитет живота локалне заједниче. У наставку, резултати истраживања показују да не постоји стастистички значајна разлика између ставова локалног становништва различитих сочио-демографских карактеристика о утицајима врњачког карневала на квалитет ниховог живота.

Кључне речи: ставови локалног становништва, туристичке манифестације, утицаји туризма, врњачки карневал, врњачка бања.

\section{Introduction}

At the global level, tourism is an industry that is growing fast and has a significant economic contribution, because it generates exports of $\$ 1.7$ trillion, 1 in 10 jobs are supported by tourism and it accounts for 10\% of global GDP (UNWTO, 2019). Tourism can be observed as one of the most important elements in achieving economic growth and development, especially in certain regions and countries that have recognized their potentials in this area in time (Papić et al., 2018). At the end of the last century it became clear that tourism has a significant impact on employment growth, foreign exchange earnings, balanced regional development and it indirectly generates benefits for other economic activities (Milićević, Podovac \& Jovanović, 2013). Although economic effects are the important and great signifier of industry success with the development of a new concept of tourism - sustainable tourism, it becomes necessary to observe and measure not only economic effects, but also ecological and socio-cultural effects of tourism. Sustainable tourism development is imperative that arises in modern conditions (Krstić et al., 2015). Tourism contributes to meeting different cultures, lifestyles, and consequently better understanding of different people (Podovac et al., 2019).

In addition, Yang, Ryan and Shang (2013) suggest that researchers need to begin to focus on the further reaching and more localized social impacts of tourism development. Generally, all impacts of tourism are reviewed from a positive or negative perspective (Usher \& Kerstetter, 2014). Tourism events are part of the tourist offer that tourism destination can directly engage in and control and are hence highly valued for their role "as attractions, catalysts, animators, place marketers, and image-makers" (Getz, 2008). Nevertheless, tourism events could add much pressure to a local infrastructure and resources for a short period of time, which could have a long-lasting effect on the host community (Li, Hsu \& Lawton, 2015).

The purpose of this paper is to examine what are the residents' attitudes towards the positive and negative impacts of tourism events, on the example of the Carnival of Vrnjci in Vrnjačka Banja. Due to its exceptional natural resources, rich cultural and 
historical heritage, long tradition in tourism, Vrnjačka Banja is nowadays one of the most popular spas in the region (Podovac \& Milićević, 2013), while in recent years it has complemented its tourism offer with events. One of the largest is the Carnival of Vrnjci, an entertaining seven-day event organized in July each year, which has over 200,000 visitors annually (Carnival of Vrnjci, 2019). This paper presents the results of an empirical study of the attitudes residents of Vrnjačka Banja municipality towards the positive and negative impacts of the Carnival of Vrnjci on the quality of their lives. Using the appropriate statistical techniques T-test and one-way analysis of variance (one-way ANOVA) the influence of the residents' socio-demographic characteristics on their attitudes towards the positive and negative impacts of the Carnival of Vrnjci was examined. The aim of the empirical research is to determine which of the sociodemographic characteristics of the local residents (gender, age, education, professional status, a distance of residents' homes from the central tourist zone of a destination, length of residence) influence attitudes towards the Carnival of Vrnjci. In addition, in order to get a better insight into local residents attitudes, the aim of the empirical research is to examine the level of agreement with the findings related to the positive and negative impacts of the Carnival of Vrnjci on the quality of their lives. According to the aims of this paper, the following main hypotheses and sub-hypotheses are defined:

- H1: The local residents of Vrnjačka Banja express more positive attitudes towards Vrnjci Carnival than the negative ones.

- H2: There is a statistically significant difference between attitudes of the local residents of different socio-demographic characteristics about the effects of Vrnjci Carnival on the quality of their lives.

o H2a: There is a statistically significant difference in the attitudes of the local residents of different gender on the positive effects of Vrnjci Carnival on the quality of their life.

o H2b: There is a statistically significant difference in the attitudes of the local residents of different gender on the negative effects of Vrnjci Carnival on the quality of their life.

o H2c: There is a statistically significant difference in the attitudes of local residents of different levels of education on the positive effects of Vrnjci Carnival on the quality of their life.

o H2d: There is a statistically significant difference in the attitudes of local residents of different levels of education on the negative effects of Vrnjci Carnival on the quality of their life.

o H2e: There is a statistically significant difference in the attitudes of the local residents of different ages on the positive effects of Vrnjci Carnival on the quality of their life.

o H2f: There is a statistically significant difference in the attitudes of the local residents of different ages on the negative effects of Vrnjci Carnival on the quality of their life.

o H2g: There is a statistically significant difference in the attitudes of the local residents of different professional status on the positive effects of Vrnjci Carnival on the quality of their life.

o H2h: There is a statistically significant difference in the attitudes of the local residents of different professional status on the negative effects of 
Vrnjci Carnival on the quality of their life.

o H2i: There is a statistically significant difference in the attitudes of the local residents about the positive effects of Vrnjci Carnival on the quality of their lives depending on the length of residence in Vrnjačka Banja.

o $\mathrm{H} 2 \mathrm{j}$ : There is a statistically significant difference in the attitudes of the local residents about the negative effects of Vrnjci Carnival on the quality of their lives depending on the length of residence in Vrnjačka Banja.

o H2k: There is a statistically significant difference in the attitudes of the local residents about the positive effects of Vrnjci Carnival on the quality of their lives depending on the place of residence in Vrnjačka Banja relative to the central tourist zone of the destination.

o H2l: There is a statistically significant difference in the attitudes of the local residents about the negative effects of Vrnjci Carnival on the quality of their lives depending on the place of residence in Vrnjačka Banja relative to the central tourist zone of the destination.

\section{Theoretical background}

Many authors investigated the impact of tourism development on the residents' quality of life (Choi \& Sirakaya, 2005; Uysal, Woo \& Singal, 2012), and the relationship between residents' attitudes of the role of tourism and quality of life (Andereck \& Nyupane, 2011; Kim, Uysal \& Sirgy, 2013). As previously mentioned, tourism may have positive and negative influence on the residents' quality of life, which can ultimately influence the residents' attitudes toward tourism (Andereck \& Nyupane, 2011). Depending on the nature of the impact, residents' support can change - positive impact induces residents to provide support for tourism development, whereas negative impact may cause residents not to provide support. Residents' support of tourism in their community is essential for tourism development, competitiveness, and sustainability (Woo, Uysal \& Sirgy, 2018).

The literature contains many factors that have been shown to influence residents attitudes toward tourism development (Sirakaya, Teye \& Sönmez, 2002). These factors include: personal economic reliance on tourism (Woo, Uysal \& Sirgy, 2018), degree of tourism concentration (Pizam 1978), level of contact with tourists (Huh \& Vogt, 2008; Sharpley, 2014), distance of residents' home from the central tourist zone of a destination (Williams \& Lawson, 2001; Jurowski \& Gursoy, 2004), length of residency in the community (Allen, Long, Perdue \& Kieselbach, 1988), the age of residents (Cavus \& Tanrisevdi, 2002; Harrill, 2004), educational level of residents (Haralambopoulos \& Pizam, 1996), level of knowledge about tourism and the local economy (Williams \& Lawson, 2001), environmental impacts (Brida, Riaño \& Aguirre, 2011), influence on tourism planning decisions, importance of the industry to the community, etc.

Numerous authors investigated the relationship between residents' attitudes of the socio-cultural impacts of tourism development, especially the role of gender, age and education level on these relationships (Andriotis \& Vaughan, 2003; Andereck \& Nyupane, 2011; Jaafar, Rasoolimanesh \& Ismail, 2017). Haralambopoulos and Pizam (1996) in their study found that the more educated residents have more positive attitudes toward tourism, while the studyby Ko and Stewart (2002) demonstrated that highly 
educated people tended to be more worried about the impacts of tourism. In terms of age of residents, Cavus and Tanrisevdi (2002) found in their study that the older residents have more negative attitudes toward tourism development in destination. Contrary to these findings, Tomljenović and Faulkner (2000) found that older residents displayed more positive attitudes toward the tourism and were more tolerant of tourists than younger residents, as well as Nunkoo and Ramkissoon (2007) who noted that younger residents have more negative attitudes towards tourism than older residents do. Regarding gender, according Harrill and Potts (2003), female residents have more negative attitudes toward negative tourism impacts; especially towards increase traffic congestion and noise, as well as to crime increase (Mason \& Cheyne, 2000). Other factors known to moderate attitudes of tourism impacts include distance of residents' home from the central tourist zone and tourist to resident ratio. According to Diedrich and Garcia-Buades (2008), when the number of tourists exceeds the number of residents, levels of tolerance can be challenged. Williams and Lawson (2001) noted that those residents living close to tourist attractions have more negative attitudes towards tourism. However, Belisle and Hoy (1980) found that the further away residents are from tourism centres, the less supportive they are of tourism development.

In terms of residents' level of involvement in tourism, some studies have shown that the residents are not satisfied, because they cannot contribute in any decision-making processes (Andereck, Valentine, Knopf \& Vogt, 2005), i.e. they could be more involved in the decision-making process about tourism development (Zamani-Farahani \& Musa, 2008). Regarding the length of residency in the destination, Williams and Lawson (2001) found that the longer the resident is a part of the community the more she/he can see the differences and impacts of tourism.

Various researchers have sought to identify the impacts of tourism events and festivals, and to explain how they influence the economic, environmental and sociocultural development of host communities (Williams \& Lawson, 2001; Andriotis \& Vaughan, 2003; Getz, 2008; Chen, 2011). Benefits that the festivals can bring to the community include job and investment opportunities, improved public facilities, preservation of local culture, and the creation of local pride, while negative impacts of the festivals can include crowding, traffic congestion, degradation of the environment, and higher costs, rates and taxes (Van Niekerk \& Coetzee, 2011).

\section{Research methodology}

In order to examine the residents' attitudes towards positive and negative impacts of the Carnival of Vrnjci on the quality of their lives, the questionnaire was formed. The survey was conducted from $1^{\text {st }}-31^{\text {st }}$ August 2019 by sending a questionnaire to the e-mail addresses of potential respondents. Before completing the questionnaire, the respondents had to answer the question whether they live in the territory of Vrnjačka Banja municipality. In this way, it was established with certainty that only the people, who live in the territory of this municipality and belong to the target group of respondents, were surveyed. The questionnaire was sent to 361 e-mail addresses of which 300 respondents $(83.1 \%)$ stated that they live in the territory of Vrnjačka Banja. If the respondent answered that he does not live in the territory of Vrnjačka Banja municipality, the link of the questionnaire was not available for completion. 
The questionnaire is divided into two segments. The first part of the questionnaire includes questions related to the basic socio-demographic characteristics of the residents (gender, age, education and professional status). Considering the subject of the survey, this part of the questionnaire also includes questions about the distance of residents' homes from the central tourist zone of a destination and length of their residence in Vrnjačka Banja municipality. Within the second part of the questionnaire, 18 statements were formed about impacts of the Carnival of Vrnjci on the residents' quality of life, with 9 constants referring to the positive and equally negative impacts of this event on the residents ' quality of life. Offered statements are related to the economic, ecological and socio-cultural impacts of the Carnival of Vrnjci on the residents` quality of life of Vrnjačka Banja. Residents provided answers using a fivepoint Likert scale $(1=$ Strongly disagree, $5=$ Strongly agree $)$. These statements were defined on the basis of an analysis of existing literature with a similar subject of research (Williams \& Lawson, 2001; Andriotis \& Vaughan, 2003; Bello, Carr, Lovelock, \& Xu, 2017; Blešić, Pivac, Besermenji, Ivkov-Džigurski \& Košić, 2014; Blešić, Pivac, Đorđević, Stamenković \& Janićević, 2014; Tepavčević, Blešić, Bradić \& Ivkov, 2019).

\section{Results of the research and discussion}

In the study of residents 'attitudes about the impact of the Carnival of Vrnjci on the quality of their life and the degree of their satisfaction with this event, 300 residents participated, of which 189 are female $(63.0 \%)$ and 111 are male (37.0\%). Residents aged 20-30 years have the highest participation in the sample (121 residents, or $40.3 \%$ ). When it comes to the level of education, the largest number of residents belongs to the category of residents that have a bachelor's degree (101 residents, or 33.7\%). Most of the residents are employed (211 residents, or $70.3 \%$ ). Of the total number of residents, the majority stated that they live near the centre of Vrnjačka Banja (156 residents, or 52.0\%). Concerning the length of residence in Vrnjačka Banja, 84 residents, or $28.0 \%$, stated that they have been living in the territory of this municipality between 20 and 30 years (Table 1).

Table 1: Socio-demographic characteristics of residents $(n=300)$

\begin{tabular}{|c|c|c|c|c|c|}
\hline & & $\mathrm{n}$ & $\%$ & M & $\mathrm{SD}$ \\
\hline \multirow[t]{2}{*}{ Gender } & Male & 111 & 37.0 & \multirow[t]{2}{*}{1.63} & \multirow[t]{2}{*}{.484} \\
\hline & Female & 189 & 63.0 & & \\
\hline \multirow[t]{5}{*}{ Age } & $20-30$ & 121 & 40.3 & \multirow[t]{5}{*}{2.01} & \multirow[t]{5}{*}{1.079} \\
\hline & $31-40$ & 98 & 32.7 & & \\
\hline & $41-50$ & 49 & 16.3 & & \\
\hline & $51-60$ & 22 & 7.3 & & \\
\hline & $>60$ & 10 & 3.3 & & \\
\hline \multirow[t]{5}{*}{ Level of education } & High school graduate & 98 & 32.7 & \multirow[t]{5}{*}{2.44} & \multirow[t]{5}{*}{1.182} \\
\hline & Vocational degree & 39 & 13.0 & & \\
\hline & Bachelor's degree & 101 & 33.7 & & \\
\hline & Master degree & 56 & 18.7 & & \\
\hline & Doctoral degree & 6 & 2.0 & & \\
\hline
\end{tabular}




\begin{tabular}{|c|c|c|c|c|c|}
\hline \multirow[t]{4}{*}{ Professional status } & Unemployed & 37 & 12.3 & \multirow[t]{4}{*}{2.14} & \multirow[t]{4}{*}{.806} \\
\hline & Employed & 211 & 70.3 & & \\
\hline & Student & 42 & 14.0 & & \\
\hline & Retired & 10 & 3.3 & & \\
\hline \multirow{4}{*}{$\begin{array}{l}\text { Part of Vrnjačka Banja } \\
\text { municipality in which } \\
\text { residents live }\end{array}$} & In the centre & 50 & 16.7 & \multirow[t]{4}{*}{2.31} & \multirow[t]{4}{*}{.932} \\
\hline & Near the centre & 156 & 52.0 & & \\
\hline & On the outskirts of the municipality & 46 & 15.3 & & \\
\hline & In the surrounding village & 48 & 16.0 & & \\
\hline \multirow{6}{*}{$\begin{array}{l}\text { How long have the } \\
\text { residentsbeen living } \\
\text { in Vrnjačka Banja } \\
\text { municipality }\end{array}$} & up to 5 years & 38 & 12.7 & \multirow[t]{6}{*}{3.93} & \multirow[t]{6}{*}{1.568} \\
\hline & $5-10$ & 21 & 7.0 & & \\
\hline & $10-20$ & 36 & 12.0 & & \\
\hline & $20-30$ & 84 & 28.0 & & \\
\hline & $30-40$ & 70 & 23.3 & & \\
\hline & $>40$ years & 51 & 17.0 & & \\
\hline
\end{tabular}

Table 2. shows the results of descriptive statistics and the Cronbach alpha coefficient, which verifies the reliability of the measurement scale.

Table 2: Descriptive statistics and Cronbach's alpha coefficient for positive impacts of Carnival of Vrnjci on the residents' quality of life

\begin{tabular}{|l|c|c|c|}
\hline Possitive impacts & M & SD & $\alpha$ \\
\hline $\begin{array}{l}\text { PI1: The Carnival of Vrnjci contributes positively to the tourism offer of Vrnjačka } \\
\text { Banja }\end{array}$ & 3.52 & 1.189 & .906 \\
\hline $\begin{array}{l}\text { PI2: Local residents are proud on the Carnival of Vrnjci because it contributes to } \\
\text { creating a sense of togetherness among the local community }\end{array}$ & 3.45 & 1.235 & .909 \\
\hline $\begin{array}{l}\text { PI3:The Carnival of Vrnjci influences on the creation of a positive image of the } \\
\text { Vrnjačka Banja }\end{array}$ & 3.83 & 1.219 & .906 \\
\hline $\begin{array}{l}\text { PI4: Local residents have equal opportunities to attend to the Carnival of Vrnjci as } \\
\text { tourists/visitors }\end{array}$ & 4.19 & 1.036 & .918 \\
\hline $\begin{array}{l}\text { PI5: The Carnival of Vrnjci creates opportunities for entertainment, social } \\
\text { interaction and meeting new people }\end{array}$ & 4.01 & 1.017 & .910 \\
\hline $\begin{array}{l}\text { PI6: The Carnival of Vrnjci creates opportunities to present talented people from } \\
\text { the local community (musicians, players, artists) }\end{array}$ & 3.83 & 1.143 & .913 \\
\hline $\begin{array}{l}\text { PI7: The Carnival of Vrnjci provide generation of additional income for the local } \\
\text { residents }\end{array}$ & 4.02 & 1.106 & .910 \\
\hline $\begin{array}{l}\text { PI8: The majority of local residents have the economic benefits from the Carnival } \\
\text { of Vrnjci }\end{array}$ & 3.46 & 1.327 & .913 \\
\hline PI9: The location at which the Carnival of Vrnjci is held is adequate & 3.81 & 1.199 & .915 \\
\hline
\end{tabular}

\section{Note: PI-Positive impact}

The residents used a five-point Likert scale to evaluate the degree of agreement with the positive impacts of the Carnival of Vrnjci on the quality of their lives. The average values for positive impacts range from 3.46 to 4.02 , while the overall mean rating of positive impacts is 3.79 , which indicates that the residents express the high level of agreement with the offered statements. With the Cronbach alpha coefficient, the reliability of the measuring scale was confirmed because the value of this coefficient for each of the offered statements is greater than 0.7 (Pallant, 2009, p.7). For the analyzed statements, the value of this coefficient ranges from .906 to .918 (Table 2). 
Table 3: Descriptive statistics and Cronbach's alpha coefficient for negative impacts of the Carnival of Vrnjci on the residents' quality of life

\begin{tabular}{|l|c|c|c|}
\hline Negative impacts & M & SD & $\alpha$ \\
\hline $\begin{array}{l}\text { NI1: The local residents are irritated by a large number of tourists/ } \\
\text { visitors of the Carnival of Vrnjci }\end{array}$ & 2.85 & 1.338 & .870 \\
\hline $\begin{array}{l}\text { NI2: During the Carnival of Vrnjci, there are traffic jams and lack of } \\
\text { parking places in Vrnjačka Banja }\end{array}$ & 4.22 & .988 & .875 \\
\hline $\begin{array}{l}\text { NI3: During the Carnival of Vrnjci, the noise level throughout the } \\
\text { destination is significantly increased }\end{array}$ & 3.74 & 1.275 & .863 \\
\hline $\begin{array}{l}\text { NI4: During the Carnival of Vrnjci, there are crowds throughout } \\
\text { Vrnjačka Banja (on the streets, promenade, parks, shops, } \\
\text { restaurants, cafes) }\end{array}$ & 4.21 & .980 & .876 \\
\hline $\begin{array}{l}\text { NI5: During the Carnival of Vrnjci, the natural resources of Vrnjačka } \\
\text { Banjaare endangered and a large amount of waste is created. }\end{array}$ & 3.45 & 1.280 & .864 \\
\hline $\begin{array}{c}\text { NI6: During the Carnival of Vrnjci, the cultural and historical heritage } \\
\text { of Vrnjačka Banja is degraded and destroyed }\end{array}$ & 2.72 & 1.238 & .863 \\
\hline $\begin{array}{c}\text { NI7: The value system and behaviour of the local residents' changes } \\
\text { negative under the influence of Carnival of Vrnjci }\end{array}$ & 2.78 & 1.195 & .862 \\
\hline $\begin{array}{c}\text { NI8: Due to the Carnival of Vrnjci prices of products and services in } \\
\text { Vrnjačka Banja increase, which is reflected in an increase in the } \\
\text { residents `cost of living }\end{array}$ & 3.64 & 1.263 & .875 \\
\hline $\begin{array}{c}\text { NI9: The Carnival of Vrnjci causes the increase of illegal and immoral } \\
\text { behaviour in Vrnjačka Banja }\end{array}$ & 2.76 & 1.320 & .861 \\
\hline
\end{tabular}

\section{Note:NI-Negative impact}

Table 3. shows the results of descriptive statistics and the Cronbach's alpha coefficient for the statements, which refer to the negative impacts of the Carnival of Vrnjci on the residents ' quality of life. Average values for negative impacts range from 2.72 to 4.22 , while the overall mean rating of negative impacts is 3.37 . The reliability of the measuring scale for each of the offered statements was tested by the Cronbach's alpha coefficient, which values range from .861 to .876 . Hypothesis H1 is confirmed by the results of descriptive statistical analysis of the residents answers. Considering that the overall mean rating of positive impacts $(M=3.79)$ is higher than the overall rating of negative impacts of the Carnival of Vrnjci on the residents' quality of life $(M=3.37)$, hypothesis $\mathrm{H} 1$ is confirmed. As the most positive influence based on the mean scores of the local residents stands out Local residents have equal opportunities to attend to the Carnival of Vrnjci as tourists/visitors ( $\mathrm{M}=4.19)$, while as the most negative influence stands out During the Carnival of Vrnjci, there are traffic jams and lack of parking places in Vrnjačka Banja $(\mathrm{M}=4.22)$.

\section{Results of t-test of independent samples and discussion}

The aim of hypothesis $\mathrm{H} 2$ is to determine which of the socio-demographic characteristics of the local residents (gender, age, education, professional status, a distance of residents' homes from the central tourist zone of a destination, length of residence) influence attitudes towards the Carnival of Vrnjci. An independent sample t-test was 
applied to examine the existence of a statistically significant difference in the attitudes of the residents of different gender about the positive and negative effects of the Carnival of Vrnjci on the quality of their lives. Hypothesis $\mathrm{H} 2$ was operationalized into a few subhypotheses (H2a-H2l). Using the t-test of independent samples, the hypothesis H2a was tested for the existence of statistically significant difference in attitudes of the local residents of different gender about the positive effects of Vrnjci Carnival on the quality of their lives. Out of the total of 9 statements related to the positive effects of Carnival of Vrnjci on the quality of life of the residents of Vrnjačka Banja, a statistically significant difference between the attitudes of the residents exists for 4 statements: The Carnival of Vrnjci contributes positively to the tourism offer of Vrnjačka Banja $(\mathrm{p}=0.041)$; The Carnival of Vrnjci influences on the creation of a positive image of the Vrnjačka Banja $(\mathrm{p}=0.004) ;$ The Carnival of Vrnjci creates opportunities for entertainment, social interaction and meeting new people $(\mathrm{p}=0.018)$ and The majority of local residents have the economic benefits from the Carnival of Vrnjci $(\mathrm{p}=0.008)$ (Table 4). Female respondents rated higher the positive impacts, with a statistically significant difference compared to male respondents. Given that a statistically significant difference was observed in 4 of the 9 statements concerning positive effects, hypothesis $\mathrm{H} 2 \mathrm{a}$ was rejected.

Table 4: Results of the t-test for positive impacts, for which a statistically significant difference in the attitudes of residents of different gender was found

\begin{tabular}{|c|c|c|c|c|c|c|}
\hline \multirow{2}{*}{$\begin{array}{l}\text { Positive } \\
\text { impacts }\end{array}$} & \multirow[b]{2}{*}{ Residents } & \multirow[b]{2}{*}{ Mean } & \multicolumn{2}{|c|}{$\begin{array}{c}\text { Levene's Test for Equality of } \\
\text { Variances }\end{array}$} & \multicolumn{2}{|c|}{ t-test for Equality of Means } \\
\hline & & & $\mathrm{F}$ & Sig. & $\mathrm{t}$ & $\mathrm{p}$ \\
\hline \multirow{2}{*}{ PI1 } & Male & 3.33 & \multirow{2}{*}{.089} & \multirow{2}{*}{.766} & \multirow{2}{*}{-2.057} & \multirow{2}{*}{.041} \\
\hline & Female & 3.62 & & & & \\
\hline \multirow[t]{2}{*}{ PI3 } & Male & 3.57 & \multirow{2}{*}{.494} & \multirow{2}{*}{.483} & \multirow{2}{*}{-2.893} & \multirow{2}{*}{.004} \\
\hline & Female & 3.98 & & & & \\
\hline \multirow[t]{2}{*}{ PI5 } & Male & 3.83 & \multirow{2}{*}{.015} & \multirow{2}{*}{.903} & \multirow{2}{*}{-2.384} & \multirow{2}{*}{.018} \\
\hline & Female & 4.12 & & & & \\
\hline \multirow{2}{*}{ PI7 } & Male & 3.20 & \multirow{2}{*}{4.853} & \multirow{2}{*}{.028} & \multirow{2}{*}{-2.679} & \multirow{2}{*}{.008} \\
\hline & Female & 3.62 & & & & \\
\hline
\end{tabular}

The accuracy of hypothesis $\mathrm{H} 2 \mathrm{~b}$ on the existence of a statistically significant difference in the attitudes of locals of different gender on the negative effects of the Carnival on their quality of life was also verified by applying a t-test of independent samples. It was found that there was no statistically significant difference in the attitudes of the residents of different gender about the negative effects of the Carnival on their quality of life, that is, no statistically significant differences were found for any of the 9 statements offered, which is why hypothesis $\mathrm{H} 2 \mathrm{~b}$ was rejected.

\section{Results of one-way analysis of variance (ANOVA) and discussion}

The purpose of applying a one-way analysis of variance ANOVA is to determine whether there is a statistically significant difference in attitudes of the local residents of 
different socio-demographic characteristics about the positive and negative influences of the Carnival on their quality of life. One-way analysis of variance examined the accuracy of the $\mathrm{H} 2 \mathrm{c}$ hypothesis that there was a statistically significant difference in the attitudes of the local residents of different degrees of education about the positive effects of the Carnival on their quality of life. A statistically significant difference in the attitudes of the residents about the positive effects of the Carnival on their quality of life at the $p \leq 0.05$ level was not found for any of the 9 statements offered, which is why the hypothesis $\mathrm{H} 2 \mathrm{c}$ was rejected. The accuracy of the $\mathrm{H} 2 \mathrm{~d}$ hypothesis is also verified by analysis of variance ANOVA. A statistically significant difference was found at $\mathrm{p} \leq 0.05$ for two of the nine claims for negative impacts: During the Carnival of Vrnjci, there are traffic jams and lack of parking places in Vrnjačka Banja $(\mathrm{F}=2.486 ; \mathrm{p}=0.044)$ and The value system and behaviour of the local residents' changes negative under the influence of Carnival of $\operatorname{Vrnjci}(\mathrm{F}=3.197, \mathrm{p}=0.014)$ (Table 5).

Table 5: ANOVA according to the level of education and negative impacts of the Carnival of Vrnjci on the life quality of residents

\begin{tabular}{|c|c|c|c|c|c|c|}
\hline \multicolumn{2}{|c|}{ Negative impacts } & Sum of Squares & $\mathrm{df}$ & Mean Square & $\mathrm{F}$ & Sig. \\
\hline \multirow{3}{*}{ NI2 } & Between Groups & 9.524 & 4 & 2.381 & \multirow{3}{*}{2.486} & \multirow{3}{*}{.044} \\
\hline & Within Groups & 282.513 & 295 & .958 & & \\
\hline & Total & 292.037 & 299 & & & \\
\hline \multirow{3}{*}{ NI3 } & Between Groups & 17.739 & 4 & 4.435 & \multirow{3}{*}{3.197} & \multirow{3}{*}{.014} \\
\hline & Within Groups & 409.178 & 295 & 1.387 & & \\
\hline & Total & 426.917 & 299 & & & \\
\hline
\end{tabular}

The attitudes of the residents, who have completed high school, and the residents with a university degree differ in their claim on creation of traffic jams and lack of parking spaces during the Vrnjci Carnival ( $\mathrm{p}=0.024)$. In addition, the attitudes of these two groups of residents differ for the statement The value system and behaviour of the local residents' changes negatively under the influence of the Carnival of Vrnjci $(\mathrm{p}=0.017)$. Given that differences between attitudes of residents of different level of education were present for only 2 of the 9 claims offered, the H2d hypothesis was rejected. Hypothesis H2e was rejected because the analysis of variance did not establish the existence of statistically significant difference between the attitudes of the residents at the level $p \leq .0 .05$ for the offered claims about the positive effects of Vrnjci Carnival on the quality of life of the residents. The one-way analysis of variance revealed the existence of a statistically significant difference in the attitudes of the residents of different ages for two of the nine offered statements about the negative effects of Vrnjci Carnival on their quality of life, namely: The local residents are irritated by a large number of tourists/visitors of the Carnival of Vrnjci $(\mathrm{F}=3.246, \mathrm{p}=0.013)$ and The value system and behaviour of the local residents' changes negative under the influence of Carnival of Vrnjci $(\mathrm{F}=2.706, \mathrm{p}=0.031)$ (Table 6). 
Table 6: ANOVA according to the age and positive impacts of the Carnival of Vrnjci on the life quality of residents

\begin{tabular}{|l|l|c|c|c|c|c|}
\hline \multicolumn{2}{|l|}{ Negative impacts } & Sum of Squares & df & Mean Square & F & Sig. \\
\hline \multirow{4}{*}{ NI1 } & Between Groups & 22.553 & 4 & 5.638 & \multirow{2}{*}{3.246} & \multirow{2}{*}{.013} \\
\cline { 2 - 5 } & Within Groups & 512.394 & 295 & 1.737 & & \\
\cline { 2 - 5 } & Total & 534.947 & 299 & & \\
\hline \multirow{3}{*}{ NI7 } & Between Groups & 15.109 & 4 & 3.777 & \multirow{2}{*}{2.706} & \multirow{2}{*}{.031} \\
\cline { 2 - 5 } & Within Groups & 411.808 & 295 & 1.396 & & \\
\cline { 2 - 5 } & Total & 426.917 & 299 & & & \\
\hline
\end{tabular}

A statistically significant difference exists for the statement The local residents are irritated by a large number of tourists/visitors of the Carnival of Vrnjci $(\mathrm{p}=0.007)$ $(\mathrm{p}=0.007)$ and for the statement The value system and behaviour of the local residents' changes negatively under the influence of the Carnival of Vrnjci $(\mathrm{p}=0.029)$ and between the residents aged 20-30 and 41-50 years of age. Considering that a statistically significant difference between the attitudes of the residents was established for only 2 of the 9 statements offered, which relate to the negative effects of Vrnjci Carnival on the quality of life of the residents, the $\mathrm{H} 2 \mathrm{f}$ hypothesis has not been proven. Hypothesis $\mathrm{H} 2 \mathrm{~g}$ was rejected due to the fact that a statistically significant difference was found for only 1 of the 9 claims offered. There is a statistically significant difference between the attitudes of the residents of different occupational status for the claim Local residents are proud on the Carnival of Vrnjci because it contributes to creating a sense of togetherness among the local community $(\mathrm{F}=4.546, \mathrm{p}=0.004)$ (Table 7$)$. If groups of residents are considered by professional status, a statistically significant difference for the stated claim is present between the residents, who have student status and are employed $(\mathrm{p}=0.002)$.

Table 7: ANOVA according to the professional status and positive impacts of the Carnival of Vrnjci on the life quality of residents

\begin{tabular}{|l|l|c|c|c|c|c|}
\hline \multicolumn{2}{|l|}{ Positive impacts } & Sum of Squares & df & Mean Square & F & Sig. \\
\hline \multirow{4}{*}{ PI2 } & Between Groups & 20.096 & 3 & 6.699 & & \multirow{3}{*}{0.546} \\
\cline { 2 - 5 } & Within Groups & 436.154 & 296 & 1.473 & \multirow{2}{*}{.004} \\
\cline { 2 - 7 } & Total & 456.250 & 299 & & & \\
\hline
\end{tabular}

In the case of testing the accuracy of hypothesis $\mathrm{H} 2 \mathrm{~h}$ on the existence of statistically significant difference in the attitudes of local residents of different professional status about the negative effects of Vrnjci Carnival on their quality of life, it was found that the same exists only in the case of the statement Due to the Carnival of Vrnjci prices of products and services in Vrnjačka Banja increase, which is reflected in an increase in residents ' cost of living $(\mathrm{F}=3.833, \mathrm{p}=0.010)$, which is why hypothesis $\mathrm{H} 2 \mathrm{~h}$ is rejected (Table 8). A statistically significant difference for the claim Due to the Carnival of Vrnjci prices of products and services in Vrnjačka Banja increase, which is reflected in an increase in residents ' cost of living, was observed in the attitudes of the local residents, who have student status and who are employed $(\mathrm{p}=0.009)$ and the local residents, who have the status of students and locals who are unemployed $(\mathrm{p}=0.029)$. The accuracy of the $\mathrm{H} 2 \mathrm{i}$ hypothesis about the existence of a statistically significant difference in the 
attitudes of the local residents about the positive effects of the Carnival on their quality of life depending on the length of residence in Vrnjačka Banja was tested using ANOVA analysis.

Table 8: ANOVA according to the professional status and negative impacts of the Carnival of Vrnjci on the life quality of residents

\begin{tabular}{|l|l|c|c|c|c|c|}
\hline \multicolumn{2}{|l|}{ Negative impacts } & Sum of Squares & df & Mean Square & F & Sig. \\
\hline \multirow{4}{*}{ NI8 } & Between Groups & 17.840 & 3 & 5.947 & & \\
\cline { 2 - 5 } & Within Groups & 459.280 & 296 & 1.552 & \multirow{2}{*}{3.833} & \multirow{2}{*}{010} \\
\cline { 2 - 5 } & Total & 477.120 & 299 & & & \\
\hline
\end{tabular}

Hypothesis $\mathrm{H} 2 \mathrm{i}$ was rejected because it was found that there was a statistically significant difference for 4 of the 9 statements: Local residents have equal opportunities to attend to the Carnival of Vrnjci as tourists/visitors $(\mathrm{F}=2.332, \mathrm{p}=0.042)$; The Carnival of Vrnjci creates opportunities for entertainment, social interaction and meeting new people, $(\mathrm{F}=2.247, \mathrm{p}=0.050)$; The Carnival of Vrnjci provide generation of additional income for the local residents $(\mathrm{F}=3.133, \mathrm{p}=0.009)$ and The location at which the Carnival of Vrnjci is held is adequate $(\mathrm{F}=2.341, \mathrm{p}=0.042)$ (Table 9).

Table 9: ANOVA according to the how long the residents live in Vrnjačka Banja and positive impacts of the Carnival of Vrnjci on the life quality of residents

\begin{tabular}{|c|c|c|c|c|c|c|}
\hline \multicolumn{2}{|c|}{ Positive impacts } & Sum of Squares & $\mathrm{df}$ & Mean Square & $\mathrm{F}$ & Sig. \\
\hline \multirow{3}{*}{ PI4 } & Between Groups & 12.236 & 5 & 2.447 & \multirow{3}{*}{2.332} & \multirow{3}{*}{.042} \\
\hline & Within Groups & 308.551 & 294 & 1.049 & & \\
\hline & Total & 320.787 & 299 & & & \\
\hline \multirow{3}{*}{ PI5 } & Between Groups & 11.373 & 5 & 2.275 & \multirow{3}{*}{2.247} & \multirow{3}{*}{.050} \\
\hline & Within Groups & 297.597 & 294 & 1.012 & & \\
\hline & Total & 308.970 & 299 & & & \\
\hline \multirow{3}{*}{ PI7 } & Between Groups & 18.511 & 5 & 3.702 & \multirow{3}{*}{3.133} & \multirow{3}{*}{.009} \\
\hline & Within Groups & 347.369 & 294 & 1.182 & & \\
\hline & Total & 365.880 & 299 & & & \\
\hline \multirow{3}{*}{ PI9 } & Between Groups & 16.469 & 5 & 3.294 & \multirow{3}{*}{2.341} & \multirow{3}{*}{.042} \\
\hline & Within Groups & 413.701 & 294 & 1.407 & & \\
\hline & Total & 430.170 & 299 & & & \\
\hline
\end{tabular}

Subsequent measurements indicated that the attitudes of residents living in Vrnjačka Banja between the ages of 5 and 10 and those living between 20-30 years differed Local residents have equal opportunities to attend to the Carnival of Vrnjci as tourists/visitors $(\mathrm{p}=0.022)$. When verifying the accuracy of hypothesis $\mathrm{H} 2 \mathrm{j}$ on the existence of a statistically significant difference in the attitudes of the local residents about the negative effects of Carnival of Vrnjci on their quality of life depending on the length of residence in Vrnjačka Banja, a statistically significant difference between the attitudes of the residents was established for the following statements: The local residents are irritated by a large number of tourists/ visitors of the Carnival of Vrnjci $(\mathrm{F}=2.961, \mathrm{p}=0.013)$; During the Carnival of Vrnjci, the natural resources of Vrnjačka Banja are endangered and a large amount of waste is created 
$(\mathrm{F}=3.639, \mathrm{p}=0.003)$ and The value system and behaviour of the local residents' changes negative under the influence of Carnival of Vrnjci $(\mathrm{F}=2.287, \mathrm{p}=0.046)$. Bearing in mind that a statistical difference exists with 3 out of 9 claims concerning the negative effects of the Carnival, hypothesis $\mathrm{H} 2 \mathrm{j}$ was rejected.

Table 10: ANOVA according to the how long have the residents been living in Vrnjačka Banja and negative impacts of the Carnival of Vrnjci on the life quality of residents

\begin{tabular}{|c|c|c|c|c|c|c|}
\hline \multicolumn{2}{|c|}{ Negative impacts } & Sum of Squares & df & Mean Square & $\mathrm{F}$ & Sig. \\
\hline \multirow{3}{*}{ NI1 } & Between Groups & 25.650 & 5 & 5.130 & \multirow{3}{*}{2.961} & \multirow{3}{*}{.013} \\
\hline & Within Groups & 509.297 & 294 & 1.732 & & \\
\hline & Total & 534.947 & 299 & & & \\
\hline \multirow{3}{*}{ NI5 } & Between Groups & 28.574 & 5 & 5.715 & \multirow{3}{*}{3.639} & \multirow{3}{*}{.003} \\
\hline & Within Groups & 461.676 & 294 & 1.570 & & \\
\hline & Total & 490.250 & 299 & & & \\
\hline \multirow{3}{*}{ NI7 } & Between Groups & 15.981 & 5 & 3.196 & \multirow{3}{*}{2.287} & \multirow{3}{*}{.046} \\
\hline & Within Groups & 410.935 & 294 & 1.398 & & \\
\hline & Total & 426.917 & 299 & & & \\
\hline
\end{tabular}

Subsequent measurements have shown that the attitudes of residents living in Vrnjačka Banja up to 5 years and those living between 20 and 30 years differ only in claim During the Carnival of Vrnjci, the natural resources of Vrnjačka Banja are endangered and a large amount of waste is created $(\mathrm{p}=0.020)$ as well as between the residents who have been living in Vrnjačka Banja for up to 5 years and those living in this place for over 40 years $(p=0.002)$. When checking the accuracy of the H2k hypothesis, it was found that there is a statistically significant difference in the attitudes of the residents depending on the place of residence about the positive effects of the the Carnival manifestation on the quality of their life in relation to the central tourist zone of the destination for the following statements: Local residents are proud on the Carnival of Vrnjci because this event contributes to creating a sense of togetherness among the local community $(\mathrm{F}=3.559, \mathrm{p}=0.018)$; Local residents have equal opportunities to attend to the Carnival of Vrnjci as tourists/visitors $(\mathrm{F}=4.471, \mathrm{p}=0.004)$ and The Carnival of Vrnjci provide generation of additional income for the local residents $(\mathrm{F}=3.475, \mathrm{p}=0.016)$ (Table 11).

Table 11: ANOVA according to place of residence and positive impacts of the Carnival of Vrnjci on the life quality of residents

\begin{tabular}{|c|c|c|c|c|c|c|}
\hline \multicolumn{2}{|c|}{ Positive impacts } & Sum of Squares & df & Mean Square & $\mathrm{F}$ & Sig. \\
\hline \multirow{3}{*}{ PI2 } & Between Groups & 15.883 & 3 & 5.294 & \multirow{3}{*}{3.559} & \multirow{3}{*}{.015} \\
\hline & Within Groups & 440.367 & 296 & 1.488 & & \\
\hline & Total & 456.250 & 299 & & & \\
\hline \multirow{3}{*}{ PI4 } & Between Groups & 13.907 & 3 & 4.636 & \multirow{3}{*}{4.471} & \multirow{3}{*}{.004} \\
\hline & Within Groups & 306.880 & 296 & 1.037 & & \\
\hline & Total & 320.787 & 299 & & & \\
\hline \multirow{3}{*}{ PI7 } & Between Groups & 12.446 & 3 & 4.149 & \multirow{3}{*}{3.475} & \multirow{3}{*}{.016} \\
\hline & Within Groups & 353.434 & 296 & 1.194 & & \\
\hline & Total & 365.880 & 299 & & & \\
\hline
\end{tabular}


The residents' attitudes living in the centre of the city and on the outskirts of the municipality differ in terms of claiming that Local residents are proud on the Carnival of Vrnjci because it contributes to creating a sense of togetherness among the local community $(\mathrm{p}=0.010)$. The attitudes who live in the centre and near the centre, differ in terms of the statement Local residents have equal opportunities to attend the Carnival of Vrnjci as tourists/visitors ( $\mathrm{p}=0.009$ ) as well as between locals living on the outskirts of the municipality and in the centre $(\mathrm{p}=0.014)$. The attitudes living in and near the centre of the centre differ in terms of claiming that The Carnival of Vrnjci provides generation of additional income for the local residents $(\mathrm{p}=0.023)$ as well as between the residents who live in the centre and at the periphery of the municipality $(p=0.023)$. Considering that there are no statistically significant differences for other claims between the attitudes of the local residents about the negative effects of the Carnival on the quality of their life from the aspect of Vrnjačka Banja residence, hypothesis H2k was rejected. When checking the accuracy of hypothesis H21, it was found that there is no statistically significant difference in the attitudes of the residents, depending on their place of residence, about the negative effects of the the Carnival manifestation on the quality of their lives, which is why this hypothesis was rejected. Hypothesis H2 on the existence of a statistically significant difference between the attitudes of the residents of different socio-demographic characteristics about the effects of the Carnival on the quality of their life has not been confirmed because none of the sub-hypotheses has been proven.

\section{Conclusion}

Events play an important role in attracting tourists and have a strong effect on the tourism development, recognition of a tourism destination and the economic activity of a country (Mandarić \& Stamenković, 2017). There are many studies that have dealt with tourism positive and negative impacts on a destination in general, but less with the focus on the tourism events, especially when it comes to the events placed in spas. Bearing this in mind, the great contribution of this article is a case study of the residents ' attitudes towards positive and negative effects of the Carnival of Vrnjci, the event that is placed in a famous Serbian spa Vrnjačka Banja.

According to this study, by observing average rates of residents 'satisfaction level with positive and negative impacts, it is confirmed that residents have rather positive attitudes towards the Carnival of Vrnjci, which means that the $\mathrm{H} 1$ is proven true. Speaking individually about the impact of the Carnival of Vrnjci on the residents quality of life, most of the residents agree that they have equal chances to visit the event as tourist/ visitors and that it may create opportunity for additional income, but on the other side most of the residents agree that there are crowds throughout the destination (on the streets, promenades, parks, shops, restaurants, cafes, etc.), traffic jams and lack of parking spaces in the destination during the event.

Considering thatthe results of T-test and one-way analysis of variance (one-way ANOVA) showed that none of the sub-hypotheses wereproved, it can be concluded that there is no statistically significant difference between the attitudes of residents of different socio-demographic characteristics about the effects of Vrnjci Carnival on their quality of life, i.e. that $\mathrm{H} 2$ is rejected. 
The main limitation of this study is the small number of residents comparing the total number of population of the Vrnjačka Banja municipality $(27,527)$ (Statistical Office of the Republic of Serbia, 2019).

The research on this basis has a perspective for further development, for improving the quality of the Carnival of Vrnjci and tourism offer of Vrnjačka Banja, as well as for the scientific basis in the form of comparative analysis of events in Vrnjačka Banja, events in other spas, events in the country, and perhaps even more widely.

\section{References}

Allen, L. R., Long, P. T., Perdue, R. R., \& Kieselbach, S. (1988). The impact of tourism development on residents' perceptions of community life. Journal of Travel Research, 27(1), 16-21.

Andereck, K.,\& Nyaupane, G. (2011). Exploring the nature of tourism and quality of life perceptions among residents. Journal of Travel Research, 50(3), 248-260.

Andereck, K., Valentine, K. M., Knopf, R., \& Vogt, C. (2005).Residents' perceptions of community tourism impacts. Annals of Tourism Research, 32(4), 1056-1076.

Andriotis, K., \& Vaughan, R. (2003). Urban residents' attitudes toward tourism development: The case of Crete. Journal of Travel Research, 42(2), 172-185.

Belisle, F.J., \& Hoy, D.R. (1980). The perceived impact of tourism by residents: A case study in Santa Marta, Colombia. Annals of Tourism Research 7(1), 83-101.

Bello, F. G., Carr, N., Lovelock, B., \& Xu, F., (2017). Local residents' perceptions of socio-cultural impacts of tourism in Mangochi, Malawi. Advances in Hospitality and Tourism Research, 5(1), 1-22.

Blešić, I., Pivac, T., Besermenji, S., Ivkov-Džigurski, A., \& Košić, K. (2014). Residents' attitudes and perception towards tourism development: A case study of rural tourism in Dragačevo, Serbia. Eastern European Countryside, 20(1), 151-165.

Blešić, I., Pivac, T., Đorđević, J., Stamenković, I., \& Janićević, S. (2014). Cultural events as part of cultural tourism development. Case study: Sombor and Apatin (Serbia). Acta geographica Slovenica, 54(2), 381-390.

Brida, J., Riaño, E., \& Aguirre, S. (2011). Residents' attitudes and perceptions towards cruise tourism development: A case study of Cartagena de Indias (Colombia). Tourism and Hospitality Research, 11(3), 181-196.

Carnival of Vrnjci (2019). About Carnival of Vrnjci. Retrieved from: 10 October 2019 http://www.vrnjackikarneval.rs/pages/okarnevalu.html

Cavus, S., \& Tanrisevdi, A. (2002). Residents' attitudes toward tourism: A case study of Kusadasi, Turkey. Tourism Analysis, 7(3), 259-268.

Chen, S.C. (2011). Residents' perceptions of the impact of major annual tourism events in Macao: cluster analysis. Journal of Convention \& Event Tourism, 12(2), 106-128.

Choi, H. S. C., \& Sirakaya, E. (2005). Measuring residents' attitude toward sustainable tourism: Development of sustainable tourism attitude scale. Journal of Travel Research, 43(4), 380-394. 
Diedrich, A., \& Garcia-Buades, E. (2009). Local perceptions of tourism as indicators of destination decline. Tourism Management, 30(4). pp. 512-521.

Getz, D. (2008). Event tourism: definition, evolution, \& research. Tourism Management, 29(3), 403-28.

Haralambopoulos, N., \& Pizam, A. (1996). Perceived impacts of tourism: The case of Samos. Annals of Tourism Research, 23(3), 503-526.

Harrill, R., \& Potts, T. (2003). Tourism planning in historic districts: Attitudes toward tourism development in Charleston. Journal of the American Planning Association, 69(3), 233-244.

Huh, C., \& Vogt, C. A. (2008). Changes in residents' attitudes toward tourism over time: a Cohort analytical approach. Journal of Travel Research, 46(4), 446-455.

Jaafar, M., Rasoolimanesh, S. M., \& Ismail, S. (2017). Perceived sociocultural impacts of tourism and community participation: A case study of Langkawi Island. Tourism and Hospitality Research, 17(2), 123-134.

Jurowski, C., \& Gursoy, D. (2004). Distance effects on residents' attitudes toward tourism. Annals of Tourism Research, 31(2), 296-312.

Kim, K., Uysal, M., \& Sirgy, M. J. (2013). How does tourism in a community impact the quality of life of community residents? Tourism Management, 36(5), 527540 .

Ko, D., \& Stewart, W. (2002). A structural equation model of residents' attitudes for tourism development. Tourism Management, 23(5), 521-530.

Krstić, B., Petrović, J., \& Stanišić, T. (2015). Analysis of key indicators of economic dimensions of spas' sustainable development in Serbia as tourism destinations. Ekonomika, 61(3), 61-71.

Li, X., Hsu, C. H. C., \& Lawton, L. J. (2015). Understanding residents' perception changes toward a mega-event through a dual-theory lens. Journal of Travel Research, 54(3), 396-410.

Mandarić, M., \& Stamenković, I. (2017). The research of the importance of events for the development and branding of the city of Niš as a tourism destination. Hotel and Tourism Management, 5(1), 64-74.

Mason, P. (2008). Tourism Impacts, Planning and Management. Amsterdam: Elsevier/ Butterworth.

Mason, P., \& Cheyne, J. (2000).Residents' attitudes to proposed tourism development. Annals of Tourism research, 27(2), 391-411.

Milićević, S., Podovac, M., \& Jovanović, D. (2013). Sustainable tourism development with special reference to the European Union. Hotel and Tourism Management, 1(1),2-30.

Milićević, S., Podovac, M. (2013). Konkurentnost Vrnjačke Banje na turističkom tržǐštu. U monografiji Konkurentnost preduzeća u Srbiji, urednici: Nebojša Janićijević, Stipe Lovreta. Univerzitet u Beogradu. Ekonomski fakultet - Centar za izdavačku delatnost, Beograd, 2017-218.

Nunkoo, R., \& Ramkissoon, H. (2007). Residents' perceptions of the socio-cultural impact of tourism in Mauritius. Anatolia, 18(1), 138-145. 
Pallant, J. (2009). SPSS priručnik za preživljavanje.Beograd: Mikroknjiga.

Papić, M., Garabinović, D., \& Blagojević, M. (2018). An overview of online marketing promotion activities in the event tourism of the Moravica district. Hotel and Tourism Management, 6(1), 41 - 51.

Pizam, A. (1978). Tourism impacts: The social costs to the destination community as perceived by its residents. Journal of Travel Research, 16(4), 8-12.

Podovac, M., Đorđević, N., \& Milićević, S. (2019). Rural tourism in the function of life quality improvement of rural population on Goč mountain. Ekonomika poljoprivrede, 66(1), 205-220.

Sharpley, R. (2014). Host perceptions of tourism: A review of the research. Tourism Management, 42(1), 37-49. DOI: 10.1016/j.tourman.2013.10.007

Sirakaya, E., Teye, V.,\& Sönmez,S. (2002). Understanding residents support for tourism development in the Central Region of Ghana. Journal of Travel Research, 41(1), 57-67.

Statistical Office of the Republic of Serbia (2019), Census 2011. Retrieved 12 October 2019 from:http://www.stat.gov.rs/en-US/oblasti/popis

Tepavčević, J., Blešić, I., Bradić, M., \& Ivkov, M. (2019).Attitudes of local residents towards tourism development in Vrbas. TIMS Acta, 13(1), 15-25.

Tomljenović, R., \& Faulkner, B. (2000). Tourism and older residents in a sunbelt resort. Annals of Tourism Research, 27(1), 93-114.

UNWTO (2019). Tourism Highlights: 2019 Edition. UNWTO: Madrid.

Usher, L. E., \& Kerstetter, D. (2014). Residents' perceptions of quality of life in a surf tourism destination: A case study of Las Salinas, Nicaragua, Progress in Development Studies, 14(4), 321-333.

Uysal, M., Woo, E., \& Singal, M. (2012). The tourist area life cycle (TALC) and its effect on the quality-of-life (QOL) of destination community. In M. Uysal, R. Perdue, \& M. J. Sirgy (Eds.), Handbook of tourism and quality-of-life research (pp. 423-443). Dordrecht, Netherlands: Springer.

Van Niekerk, M., \& Coetzee, W. J. L. (2011). Utilizing the VICE model for the sustainable development of the Innibos Arts Festival. Journal of Hospitality Marketing \& Management, 20(3-4), 347-365.

Williams, J., \& Lawson, R. (2001).Community issues and resident opinions of tourism. Annals of Tourism Research, 28(2), 269-290.

Woo, E., Uysal, M., \& Sirgy, M.J. (2018). Tourism impact and stakeholders' quality of life. Journal of Hospitality \& Tourism Research, 42(2), 260-286.

Yang, J., Ryan, C.,\& Shang, L. (2013).Social conflict in communities impacted by tourism. Tourism Management 35, 82-93.

Zamani-Farahani, H., \& Musa, G. (2008). Residents' attitudes and perception towards tourism development: A case study of Masooleh, Iran. Tourism Management, 29(6), 1233-1236. 